\title{
Effects of neem, betel leaf, devil's tree, jute and turmeric against gastrointestinal nematodes in sheep
}

\author{
M. R. Amin ${ }^{1}$, M. Mostofa ${ }^{2}$, M. N. Islam ${ }^{3}$ and M. A. Asgar ${ }^{4}$ \\ ${ }^{1 \& 4}$ Department of Physiology, Biochemistry and Pharmacology, FANSVM, PSTU \\ ${ }^{283}$ Department of Pharmacology, Bangladesh Agricultural University, Mymensingh
}

\begin{abstract}
Effects of neem, betel leaf, devil's tree, jute and turmeric against natural gastrointestinal nematodes in sheep and on some hematological parameters (TEC, Hb and PCV) and body weight were studied. Thirty (30) naturally parasitized sheep were randomly divided into six groups(A, B, C, D, E and F), each consisting of five sheep. Ten percent water extract of leaves of neem, betel leaf, devil's tree and jute were administered orally to the sheep of group A, B, C and $\mathrm{D}$, respectively. Sheep of group $\mathrm{E}$ was treated orally with $10 \%$ water extract of rhizome of turmeric. Sheep of group $\mathrm{F}$ was kept as infected control group. Fecal samples, hematological parameters and body weight were examined before treatment and on $7^{\text {th }}, 14^{\text {th }}, 21^{\text {st }}$ and $28^{\text {th }}$ day. A significant $(\mathrm{p}<0.01)$ reduction of EPG count was found following administration of neem (37.60-47.03\%), betel leaf (6.43-14.00\%), devil's tree (3.04-11.04\%), jute (0.50-5.26\%) and turmeric $(0.46-8.30)$ in sheep. The EPG count of the control group $(F)$ were significantly $(p<0.01)$ increased up to the last day of experimental period. After treatment with neem, betel leaf, devil's tree, jute and turmeric total erythrocyte count (TEC), hemoglobin $(\mathrm{Hb})$ content and packed cell volume (PCV) were increased significantly $(p<0.01$ and $p<0.05)$ in sheep. The body weight was increased significantly $(p<0.01$ and $p<0.05)$ in neem, betel leaf, devil's tree, jute and turmeric treated sheep. On the other hand, body weight was decreased in untreated control group. The present study reveal that $10 \%$ water extract of neem was moderately effective and betel leaf, devil's tree, jute and turmeric were relatively less effective against gastrointestinal nematodes in sheep.
\end{abstract}

Keywords: Neem, Betel leaf, Devil's tree, Jute, Turmeric, Gastrointestinal nematode

\section{Introduction}

Parasitism is an important limiting factor responsible for deteriorating the health and productivity of livestock. The agro-ecological and geo-climatic conditions of Bangladesh are highly favorable for the growth and multiplication of parasites. The greatest losses associated with nematode infections are subclinical and economic assessments have showed that financial costs of internal parasitism are enormous (Preston and Allonby, 1979; McLeod, 1995). Control of parasitic diseases has been mainly based on regular anthelmintic treatment in Bangladesh. However, as these are very expensive and unavailable to farmers in rural areas, livestock producers are not interested to use these anthelmintics. Furthermore, some serious disadvantages of using those anthelmintics, notably the development of resistance to helminth parasites (Waller and Prichard, 1985; Lans and Brown, 1998) against various anthelmintic compounds and classes, as well as their residues and toxicity problems (Kaemmerer and Butenkotter, 1973). Medicinal plants are one of the most important natural resources of a country. World Health Organization (WHO, 1993) has recognized the necessity for investigation and mobilization of ancient medicinal practices to fulfill the primary health care systems of the man and animals, and realizes that the traditional system of medicine may play an important role in the development of livestock of the third world countries. Plant remedies were also extensively used as anthelmintics in the developed world before the era of broad-spectrum synthetic drugs (British Veterinary Codex, 1953). Many currently available therapeutic compounds are plant derived and/or synthetic analogues derived from those compounds (Farnsworth et al., 1985). For these reasons, interest in the screening of medicinal plants for their anthelmintic activity has remained of great scientific interest despite extensive use of synthetic chemicals in modern clinical practices all over the world (Akhtar et al., 2000). The present study was undertaken to evaluate the efficacy of neem (Azadirachta indica), betel leaf (Piper betle), devil's tree (Alstonia scholaris), jute (Corchorus capsularis) and turmeric (Curcuma longa) against gastrointestinal nematodes in sheep. The effects of neem, betel leaf, devil's tree, jute and turmeric on hematological parameters (TEC, Hb and PCV) and body weight were also determined in this study. 


\section{Materials and Methods}

The experiment was performed in the Department of Pharmacology, Faculty of Veterinary Science, Bangladesh Agricultural University (BAU), Mymensingh during the period between $1^{\text {st }}$ March, 2004 to $28^{\text {th }}$ March, 2004. Sixty sheep (approximately 2-3 years old) were selected for this study which were suspected to be suffering from natural gastrointestinal nematodes infection and they were marked at the ears by the numbered tag. Examination of fecal samples for gastrointestinal nematodes egg counts by floatation method (Rahman et al., 1996) were carried out over a week prior to commencement of treatment. On the basis of fecal sample examination results, 30 sheep of both sexes infected with gastrointestinal nematodes were selected for this study and randomly divided into six groups $(A, B, C, D$, $\mathrm{E}$ and $\mathrm{F}$ ), each group consisting of five sheep.Ten Percent water extract of leaves of neem (Azadirachta indica), betel leaf ( Piper betle), devil's tree ( Alstonia scholaris ), jute (Corchorus capsularis ) and turmeric (Curcuma longa) were administered orally to the sheep of group A, B, C and D, respectively. Sheep of group $E$ was treated orally with $10 \%$ water extract of rhizome of turmeric. Sheep of group $F$ were kept as infected control without giving any treatment.

The fecal sample from all groups were examined by egg counting McMaster method as described by Soulsby (1986) before treatment (day 0) and at $7^{\text {th }}, 14^{\text {th }}, 21^{\text {st }}$ and $28^{\text {th }}$ day of post-treatment. Egg per gram (EPG) of feces were recorded. Blood samples were collected from the jugular vein of each sheep at different time intervals mentioned above. Various hematological parameters (TEC, Hb and PCV) were measured following the method of Coffin (1953). To determine the body weight gain or loss of treated and untreated control groups, body weight was taken on day 0 (pretreatment) and on $7^{\text {th }}, 14^{\text {th }}, 21^{\text {st }}$, and $28^{\text {th }}$ day of experimental period. Collected data were statistically analyzed by the computer using statistical package programme MSTAT-C developed by Russel (1996).

\section{Results and Discussion}

The results of the effect of neem, betel leaf, devil's tree, jute and turmeric against gastrointestinal nematodes in sheep were shown in Table 1. A significant $(p<0.01)$ reduction of EPG counts were found on $7^{\text {th }}, 14^{\text {th }}, 21^{\text {st }}$ and $28^{\text {th }}$ day following neem, betel leaf, devil's tree, jute and turmeric treated sheep of group $A, B, C, D$ and $E$, respectively. Whereas, the EPG count of untreated control group (F) were significantly $(p<0.01)$ increased up to last day of experimental period. In conformity to the present findings, Rob et al. (2004) observed that water extracts of neem was $53.72 \%$ effective against gastrointestinal nematodes (Haemonchus contortus) in sheep. Brelin (2002) found that fresh neem leaves significantly reduced $H$. contortus in the abomasum of the treated sheep. Arunachal et al. (2002) noted that neem leaves, seeds and bark were $53 \%, 49 \%$ and $38 \%$ infective against gastrointestinal helminths in sheep, respectively. Amin et al. (2008) reported that neem (10\% water extract of leaves) reduced significantly $(p<0.01)$ EPG count $62.23 \%, 65.77 \%, 56.70 \%$ and $48.05 \%$ on $3^{\text {rd }}, 10^{\text {th }}, 17^{\text {th }}$ and $28^{\text {th }}$ day, respectively in cattle. Rahman (2002) found the effects of water extract of neem, betel leaf and jute leaves were $62 \%, 58 \%$ and $42 \%$, respectively in goat on $21^{\text {st }}$ day post-treatment.

The results of the effect of neem, betel leaf, devil's tree, jute and turmeric on hematological parameters (TEC, $\mathrm{Hb}$ and PCV) in sheep are shown in Table 2, 3 and 4. After treatment with neem, total erythrocyte count (TEC), hemoglobin ( $\mathrm{Hb})$ content and packed cell volume (PCV) were increased significantly $(p<0.01$ and $p<0.05)$ at $7^{\text {th }}, 14^{\text {th }}, 21^{\text {st }}$, and $28^{\text {th }}$ day post-treatment in sheep. Conversely, TEC, Hb and PCV were decreased significantly $(p<0.01$ and $p<0.05)$ up to the last day of experimental period in untreated infected group. Rob et al. (2004) stated that water extracts of neem leaves increased TEC, $\mathrm{Hb}$ content, PCV in sheep on 28 day post-treatment. Likewise, Rahman (2002) observed water extract of neem, betel leaf and jute leaves increased TEC, $\mathrm{Hb}$ content on $21^{\text {st }}$ day of post-treatment in goat. Similarly, Amin et al. (2008) reported that neem (10\% water extract of leaves) increased TEC, Hb content, PCV in cattle on 28 day post-treatment. Hossain et al. (1996) also reported that neem leaves increased $\mathrm{Hb}$ content in cattle. 
Table 1. Effects of Neem, Betel leaf, Devil's tree, Jute and Turmeric against gastrointestinal nematodes in sheep

\begin{tabular}{|c|c|c|c|c|c|c|c|c|c|c|}
\hline \multirow[b]{3}{*}{ Group } & \multirow[b]{3}{*}{ Treatment } & \multirow{3}{*}{$\begin{array}{c}\text { Pretreatment } \\
\text { '0' day } \\
\text { EPG } \\
\text { Mean } \pm \text { SD }\end{array}$} & \multicolumn{8}{|c|}{ Post-treatment } \\
\hline & & & \multicolumn{2}{|c|}{$7^{\text {th }}$ day } & \multicolumn{2}{|c|}{$14^{\text {th }}$ day } & \multicolumn{2}{|c|}{$21^{\text {st }}$ day } & \multicolumn{2}{|c|}{$28^{\text {th }}$ day } \\
\hline & & & $\begin{array}{c}E P G \\
\text { mean } \pm \text { SD }\end{array}$ & $\begin{array}{c}\text { EPG } \\
\text { increase/ } \\
\text { decrease } \\
(\%)\end{array}$ & $\begin{array}{c}\text { EPG } \\
\text { mean } \pm \\
\text { SD }\end{array}$ & $\begin{array}{c}\text { EPG } \\
\text { increase/ } \\
\text { decrease } \\
(\%)\end{array}$ & $\begin{array}{c}\text { EPG } \\
\text { mean } \pm \\
\text { SD }\end{array}$ & $\begin{array}{c}\text { EPG } \\
\text { increase/ } \\
\text { decrease } \\
(\%)\end{array}$ & $\begin{array}{c}\text { EPG } \\
\text { mean } \pm \\
\text { SD }\end{array}$ & $\begin{array}{c}\text { EPG } \\
\text { increase/ } \\
\text { decrease } \\
(\%)\end{array}$ \\
\hline A & Neem & $\begin{array}{c}289.60 \pm \\
7.07\end{array}$ & $\begin{array}{c}153.40 \\
\pm \\
7.07^{\star \star}\end{array}$ & $\begin{array}{c}47.03 \\
(-)\end{array}$ & $\begin{array}{c}155.60 \\
\pm \\
7.07^{\star *}\end{array}$ & $\begin{array}{c}46.27 \\
(-)\end{array}$ & $\begin{array}{c}168.50 \\
\pm \\
7.07^{\star *}\end{array}$ & $\begin{array}{c}41.82 \\
(-)\end{array}$ & $\begin{array}{c}180.70 \\
\pm \\
7.07^{\star *}\end{array}$ & $\begin{array}{c}37.60 \\
(-)\end{array}$ \\
\hline B & Betel leaf & $\begin{array}{c}265.80 \\
\pm \\
3.54\end{array}$ & $\begin{array}{c}228.60 \\
\pm \\
7.07^{\star \star}\end{array}$ & $\begin{array}{c}14.00 \\
(-)\end{array}$ & $\begin{array}{c}229.80 \\
\pm \\
7.07^{\star \star}\end{array}$ & $\begin{array}{c}13.54 \\
(-)\end{array}$ & $\begin{array}{c}242.30 \\
\pm \\
1.41^{\star \star}\end{array}$ & $\begin{array}{c}8.84 \\
(-)\end{array}$ & $\begin{array}{c}248.70 \\
\pm \\
8.37^{\star \star}\end{array}$ & $\begin{array}{c}6.43 \\
(-)\end{array}$ \\
\hline C & Devil's tree & $\begin{array}{c}262.80 \\
\pm \\
7.13\end{array}$ & $\begin{array}{c}233.80 \\
\pm \\
2.12^{\star \star}\end{array}$ & $\begin{array}{c}11.04 \\
(-)\end{array}$ & $\begin{array}{c}236.80 \\
\pm \\
4.24^{\star \star}\end{array}$ & $\begin{array}{c}9.89 \\
(-)\end{array}$ & $\begin{array}{c}245.60 \\
\pm \\
3.54^{\star \star}\end{array}$ & $\begin{array}{c}6.54 \\
(-)\end{array}$ & $\begin{array}{c}254.80 \\
\pm \\
4.47^{\star \star}\end{array}$ & $\begin{array}{c}3.04 \\
(-)\end{array}$ \\
\hline D & Jute & $\begin{array}{c}342.40 \\
\pm \\
1.41\end{array}$ & $\begin{array}{c}324.40 \\
\pm \\
7.07^{\star \star}\end{array}$ & $\begin{array}{c}5.26 \\
(-)\end{array}$ & $\begin{array}{c}328.80 \\
\pm \\
0.00^{\star *}\end{array}$ & $\begin{array}{c}3.97 \\
(-)\end{array}$ & $\begin{array}{c}334.20 \\
\pm \\
0.00^{\star \star}\end{array}$ & $\begin{array}{c}2.39 \\
(-)\end{array}$ & $\begin{array}{c}340.70 \\
\pm \\
7.07^{\star \star}\end{array}$ & $\begin{array}{c}0.50 \\
(-)\end{array}$ \\
\hline$E$ & Turmeric & $\begin{array}{c}282.00 \\
\pm \\
7.07\end{array}$ & $\begin{array}{c}258.60 \\
\pm \\
5.66^{\star \star}\end{array}$ & $\begin{array}{c}8.30 \\
(-)\end{array}$ & $\begin{array}{c}264.40 \\
\pm \\
0.00^{\star \star}\end{array}$ & $\begin{array}{c}6.24 \\
(-)\end{array}$ & $\begin{array}{c}272.20 \\
\pm \\
0.00^{\star \star}\end{array}$ & $\begin{array}{c}3.48 \\
(-)\end{array}$ & $\begin{array}{c}280.70 \\
\pm \\
0.00^{\star \star}\end{array}$ & $\begin{array}{c}0.46 \\
(-)\end{array}$ \\
\hline $\mathrm{F}$ & Control & $\begin{array}{c}246.20 \\
\pm \\
19.29\end{array}$ & $\begin{array}{c}265.60 \\
\pm \\
22.08^{\star \star}\end{array}$ & $\begin{array}{c}7.88 \\
(+)\end{array}$ & $\begin{array}{c}274.40 \\
\pm \\
11.31^{\star \star}\end{array}$ & $\begin{array}{c}11.45 \\
(+)\end{array}$ & $\begin{array}{c}295.80 \\
\pm \\
16.20^{\star \star}\end{array}$ & $\begin{array}{c}20.15 \\
(+)\end{array}$ & $\begin{array}{c}320.70 \\
\pm \\
24.49^{\star *}\end{array}$ & $\begin{array}{c}30.26 \\
(+)\end{array}$ \\
\hline
\end{tabular}

The above values represent the mean \pm standard deviation (SD) of 5 sheep $\quad$ ' + ' $=$ Increase

** = Significant at 1 per cent level $(p<0.01)$

* = Significant at 5 per cent level $(p<0.05)$

'-' = Decrease

Table 2. Effects of Neem, Betel leaf, Devil's tree, Jute and Turmeric on TEC (million/cu.mm) in sheep

\begin{tabular}{|c|c|c|c|c|c|c|}
\hline \multirow{2}{*}{ Group } & \multirow{2}{*}{ Treatment } & Pretreatment & \multicolumn{4}{|c|}{ Post-treatment } \\
\cline { 3 - 6 } & & $0^{\prime}$ ' day & $7^{\text {th }}$ day & $14^{\text {th }}$ day & $21^{\text {st }}$ day & $28^{\text {th }}$ day \\
\hline A & Neem & $8.26 \pm 0.14$ & $8.97 \pm 0.64^{\star}$ & $8.84 \pm 0.57^{\star \star}$ & $8.70 \pm 0.70^{\star \star}$ & $8.53 \pm 0.35^{\star}$ \\
\hline B & Betel leaf & $8.46 \pm 0.28$ & $8.72 \pm 0.00^{\star}$ & $8.70 \pm 0.00^{\star \star}$ & $8.65 \pm 0.42^{\star \star}$ & $8.54 \pm 0.35^{\star}$ \\
\hline C & Devil's tree & $8.12 \pm 0.01$ & $8.38 \pm 0.00^{\star}$ & $8.32 \pm 0.21^{\star \star}$ & $8.26 \pm 0.71^{\star \star}$ & $8.18 \pm 0.71^{\star}$ \\
\hline D & Jute & $8.65 \pm 0.00$ & $8.75 \pm 0.49^{\star}$ & $8.75 \pm 0.00^{\star \star}$ & $8.70 \pm 0.00^{\star \star}$ & $8.68 \pm 0.42^{\star}$ \\
\hline E & Turmeric & $8.32 \pm 0.21$ & $8.65 \pm 0.42^{\star}$ & $8.64 \pm 0.52^{\star \star}$ & $8.50 \pm 0.00^{\star \star}$ & $8.48 \pm 0.00^{\star}$ \\
\hline F & Control & $8.60 \pm 0.42$ & $8.10 \pm 0.07^{\star}$ & $7.97 \pm 0.71^{\star \star}$ & $7.54 \pm 0.35^{\star \star}$ & $7.22 \pm 0.14^{\star}$ \\
\hline
\end{tabular}

The above values represent the mean \pm standard deviation (SD) of 5 sheep

** = Significant at 1 per cent level $(p<0.01)$

$*$ = Significant at 5 per cent level $(p<0.05)$

Table 3. Effects of Neem, Betel leaf, Devil's tree, Jute and Turmeric on $\mathrm{Hb}$ (gm \%) in sheep

\begin{tabular}{|c|c|c|c|c|c|c|}
\hline \multirow{2}{*}{ Group } & \multirow{2}{*}{ Treatment } & Pretreatment & \multicolumn{4}{|c|}{ Post-treatment } \\
\cline { 3 - 7 } & & '0' day & $7^{\text {th }}$ day & $14^{\text {th }}$ day & $21^{\text {st }}$ day & $28^{\text {th }}$ day \\
\hline A & Neem & $7.40 \pm 0.14$ & $7.90 \pm 0.64$ & $7.80 \pm 0.14^{\star}$ & $7.60 \pm 0.14$ & $7.50 \pm 0.35^{\star}$ \\
\hline B & Betel leaf & $7.60 \pm 0.12$ & $7.90 \pm 0.14$ & $7.90 \pm 0.07$ & $7.80 \pm 0.14$ & $7.70 \pm 1.41^{*}$ \\
\hline C & Devil's tree & $7.50 \pm 0.35$ & $7.70 \pm 0.49$ & $7.70 \pm 0.14$ & $7.60 \pm 0.42$ & $7.60 \pm 0.00^{\star}$ \\
\hline D & Jute & $7.30 \pm 0.21$ & $7.60 \pm .07$ & $7.90 \pm 0.89^{\star}$ & $7.40 \pm 1.41$ & $7.40 \pm 0.28^{\star}$ \\
\hline E & Turmeric & $7.44 \pm 0.22$ & $7.80 \pm 0.00$ & $7.70 \pm 0.89^{\star}$ & $7.70 \pm 0.00$ & $7.50 \pm 0.00^{*}$ \\
\hline F & Control & $7.90 \pm 0.14$ & $7.70 \pm 0.71$ & $7.40 \pm 0.28^{\star}$ & $7.20 \pm 0.42$ & $7.00 \pm 0.35^{\star}$ \\
\hline
\end{tabular}

The above values represent the mean \pm standard deviation (SD) of 5 sheep

** = Significant at 1 per cent level $(p<0.01)$

* = Significant at 5 per cent level $(p<0.05)$ 
Table 4. Effects of Neem, Betel leaf, Devil's tree, Jute and Turmeric on PCV (\%) in sheep

\begin{tabular}{|c|c|c|c|c|c|c|}
\hline \multirow{2}{*}{ Group } & \multirow{2}{*}{ Treatment } & Pretreatment & \multicolumn{4}{|c|}{ Post-treatment } \\
\cline { 3 - 7 } & & '0' day & $7^{\text {th }}$ day & $14^{\text {th }}$ day & $21^{\text {st }}$ day & $28^{\text {th }}$ day \\
\hline A & Neem & $29.00 \pm 0.71$ & $31.50 \pm 2.12^{\star \star}$ & $31.50 \pm 0.71^{\star \star}$ & $31.00 \pm 0.71^{\star \star}$ & $30.50 \pm 1.41^{\star \star}$ \\
\hline B & Betel leaf & $29.50 \pm 1.41$ & $31.50 \pm 0.79^{\star \star}$ & $31.00 \pm 0.00^{\star \star}$ & $31.00 \pm 0.71^{\star \star}$ & $30.00 \pm 1.41^{\star \star}$ \\
\hline C & Devil's tree & $28.00 \pm 2.12$ & $30.00 \pm 2.83^{\star \star}$ & $29.00 \pm 0.00^{\star \star}$ & $28.50 \pm 2.12^{\star \star}$ & $28.50 \pm 0.00^{\star \star}$ \\
\hline D & Jute & $28.50 \pm 0.00$ & $29.50 \pm 0.00^{\star \star}$ & $29.00 \pm 1.41^{\star \star}$ & $29.00 \pm 0.00^{\star \star}$ & $28.50 \pm 0.00^{\star \star}$ \\
\hline E & Turmeric & $30.50 \pm 3.54$ & $31.50 \pm 0.71^{\star \star}$ & $31.50 \pm 0.71^{\star \star}$ & $31.00 \pm 0.71^{\star \star}$ & $30.00 \pm 2.12^{\star \star}$ \\
\hline F & Control & $30.50 \pm 1.41$ & $29.00 \pm 0.71^{\star \star}$ & $29.00 \pm 0.71^{\star \star}$ & $28.50 \pm 1.41^{\star \star}$ & $27.00 \pm 1.41^{\star \star}$ \\
\hline
\end{tabular}

The above values represent the mean \pm standard deviation (SD) of 5 sheep

** = Significant at 1 per cent level $(p<0.01)$

* = Significant at 5 per cent level $(p<0.05)$

The results of neem, betel leaf, devil's tree, jute and turmeric on body weight in sheep are shown in Table 5. Neem, betel leaf, devil's tree, jute and turmeric significantly $(p<0.01$ and $p<0.05)$ increased body weight in group $A, B, C, D$ and $E$, respectively. On the other hand, body weight was decreased significantly $(p<0.01$ and $p<0.05)$ in untreated controlled sheep of group $F$. These results were agreeable with the findings of Ahmed et al. (1994) in sheep. They observed body weight of neem seeds treated sheep was increased (6.74\%)and decreased live weight value in untreated sheep. Similarly, Amin et al. (2008) reported that body weight was increased significantly in neem treated cattle and decreased in untreated cattle. Hossain et al. (1996) also observed neem leaves and neem seed kernels increased body weight of cattle. The body weight was increased might be due to removal of parasitic load which facilitate the weight regain through proper digestion, absorption and metabolism of feed nutrients.

Table 5. Effects of Neem, Betel leaf, Devil's tree, Jute and Turmeric on body weight $(\mathrm{kg})$ in sheep

\begin{tabular}{|c|c|c|c|c|c|c|}
\hline \multirow{2}{*}{ Group } & \multirow{2}{*}{ Treatment } & Pretreatment & \multicolumn{4}{|c|}{ Post-treatment } \\
\cline { 3 - 7 } & & $' 0 ’$ day & $7^{\text {th }}$ day & $14^{\text {th }}$ day & $21^{\text {st }}$ day & $28^{\text {th }}$ day \\
\hline A & Neem & $15.92 \pm 0.71$ & $16.00 \pm 0.00^{\star \star}$ & $16.26 \pm 0.71^{\star}$ & $16.05 \pm 0.89^{\star}$ & $16.02 \pm 0.00^{\star \star}$ \\
\hline B & Betel leaf & $15.58 \pm 0.35$ & $15.96 \pm 0.71^{\star \star}$ & $16.10 \pm 0.11^{\star}$ & $16.35 \pm 2.12^{\star}$ & $16.15 \pm 0.07$ \\
\hline C & Devil's tree & $15.86 \pm 0.00$ & $16.20 \pm 0.71^{\star \star}$ & $16.44 \pm 0.31^{\star}$ & $16.35 \pm 1.41^{*}$ & $16.10 \pm 0.00$ \\
\hline D & Jute & $16.24 \pm 0.00$ & $16.37 \pm 0.21^{\star \star}$ & $16.40 \pm 0.28^{\star}$ & $16.40 \pm 0.00^{\star}$ & $16.30 \pm 0.71$ \\
\hline E & Turmeric & $15.48 \pm 0.00$ & $15.60 \pm 0.00^{\star \star}$ & $15.72 \pm 0.00^{\star}$ & $15.80 \pm 0.00^{\star}$ & $15.65 \pm 0.71$ \\
\hline F & Control & $16.46 \pm 1.22$ & $15.95 \pm 1.48^{\star *}$ & $15.83 \pm 2.12^{\star}$ & $15.21 \pm 0.71^{*}$ & $15.10 \pm 1.41^{\star \star}$ \\
\hline
\end{tabular}

The above values represent the mean \pm standard deviation (SD) of 5 sheep

** $=$ Significant at 1 per cent level $(p<0.01)$

* = Significant at 5 per cent level $(p<0.05)$

It may be concluded that watery extracts of neem leaves was moderately effective against gastrointestinal nematodes in sheep and may be used as an alternative drugs in field condition of Bangladesh. The present study is a preliminary work on the medicinal plants in sheep in Bangladesh. However, further studies on its pharmacokinetic and toxic effects is needed before carrying out extensive field use in Bangladesh.

\section{Acknowledgement}

The financial support of BAURES, Bangladesh Agricultural University, Mymensingh for conducting the experiment is gratefully acknowledged.

\section{References}

Ahmed, N.U., Mostofa, M., Awal, M. A. and Alam, M.N. 1994. Comparative efficacy of modern anthelmintics with that of neem seeds against gastrointestinal nematodiasis in sheep. Bangladesh Veterinary Journal, 28: 21-23.

Akhtar, M.S., Iqbal, Z., Khan, M.N. and Lateef, M. 2000. Anthelminitic activity of medicinal plants with particular reference to their use in animals in the Indo-Pakistan subcontinent. Small Ruminant Research., 38: 99-107. 
Amin, M.R., Mostofa, M., Awal, M.A. and Hossain, A. 2008. Effects of neem (Azadirachta indica) leaves against gastrointestinal nematodes in cattle. Journal of Bangladesh Agricultural University, 6(1): 87-99.

Arunachal, P.K., Karunanithi, K. and Narendrababu, R. 2002. Comparative study on anthelmintic efficacy of neem products and praziplus in sheep. Indian Journal of Small Ruminant. 8(2): 131-132.

Brelin, D. 2002. Evaluation of the neem tree (Azadirachta indica) as an alternative anthelmintic for helminth control in small ruminants in Malaysia. Minor Field Studies International Office, Swedish University of Agricultural Sciences, 196: 31.

British Veterinary Codex. 1953. British Veterinary Codex. The Pharmaceutical Press, London, 189 pp.

Coffin, D.L. 1953. Manual of Veterinary Clinical Pathology. $3^{\text {rd }}$ edn., Coinstock Publishing Associates Inc. Ithaca, New York, $116-157$ pp.

Farnsworth, N.R., Akerele, O., Bingel, A.S., Soejarto, D.D. and Guo, Z. 1985. Medicinal plants in therapy. Bull. World Health Organization, 63: 965-981.

Hossain, S.A., Mostofa, M., Alam, M.N., Awal, M.A. and Ahmed, N.U. 1996. Comparative efficacy of modern anthelmintics and neem (leaves and seeds) in the treatment of bovine nematodiasis. Progressive Agriculture. 7(1): 29-33.

Kaemmerer, K. and Butendotter, S. 1973. The problem of residues in meat of edible domestic animals after application or intake of organophosphate esters. Residure Review, 46: 1.

Lans, C. and Brown, G. 1998. Ethnoveterinary medicines used for ruminants in Trinidad and Tobago. Preventive Veterinay Medicine, 35: 149-163.

McLeod, R.S. 1995. Costs of major parasites to the Australian livestock industries. International Journal of Parasitology, 25: 13631367.

Preston, J.M. and Allonby, E.W. 1979. The influence of breed on the susceptibility of sheep of Haemonchus contortus infection in Kenya. Research in Veterinary Science, 26: 34-139.

Rahman, M. 2002. In vitro and in vivo anthelmintic effects of some plants against gastrointestinal nematodes of goats. M.S. Thesis, submitted to the Department of Parasitology, Bangladesh Agricultural University, Mymensingh.

Rahman, M.H. Ahmed, S. and Mondal, M.M.H. 1996. Introduction to helminth parasites of animals and birds in Bangladesh. $1^{\text {st }}$ edn., Sheba Printing Press. Bangladesh, 16-17 pp.

Rob, S., Mostofa, M., Awal, M.A., Shahiduzzaman, M. and Sardar, S.A. 2004. Comparative efficacy of albendazole (Endokil $\left.{ }^{\circledR}\right)$ and neem (Azadirachta indica) leaves extract against hemonchosis in sheep. Progressive Agriculture, 15(2): 33-39.

Russel, D.F. 1996. MSTAT Director. Crop and Soil Science Department, Michigan State University, USA.

Soulsby, E.J.L. 1986. Helminth, Arthropod and Protozoa of Domesticated Animals. $7^{\text {th }}$ edn., Bailliere and Tindall, London, $763-766$ pp.

Waller, P.J. and Prichard, R.K. 1985. Drug resistance in nematodes. In: Campbell, W.C., Rew, R.S. (Eds), Chemotherapy of Parasitic Infections. Phenum, New York, USA, 339-362 pp.

WHO. 1993. Summary of WHO guidelines for assessment of Herbal Medicines. Herbal Gram, 28: 13-14. 